УДК 639.371 .52

(C) 2017

Грициняк І. І. доктор сільськогосподарських наук, професор, академік НААН, Гурбик В. В. аспірант

(науковий керівник - доктор сільськогосподарських наук, професор, академік НААН І. І. Гриииняк)

Інститут рибного господарства НААН

\title{
РИБОГОСПОДАРСЬКА ОЦІНКА ТОВАРНИХ ТРИЛІТОК ГАЛИЦЬКОГО КОРОПА
}

\section{Рецензент - доктор сільськогосподарських наук В. В. Бех}

Визначено основні рибогосподарські характеристики триліток галицького коропа, отриманих в умовах ставового вирощування. Екологічні умови під час вирощування триліток галицького коропа були в межах рибницьких вимог. В кінці вететаційного сезону отримані трилітки характеризувались високою індивідуальною масою. Вихід риб з нагулу коливався від $96 \%$ до 98\%. Показник рибопродуктивності перевищчив 2000 кг/га. Інтенсивне підвищення маси тіла рибопосадкового матеріалу у 2015 році зафіксовано протягом другої декади липня, в цей період абсолютний ваговий приріст їх перевищив такий 2016 року майже на 200 г. Основний же пік вагового росту риб y 2016 рочі спостерігався на початку липня. Найменші показники вагового росту протягом експериментального періоду відмічено у травні. У 2015 році тенденція на спад прослідковується також на початку липня. За показником питомої швидкості росту встановлено пік зростання ї̈ у другій декаді липня. Мінімальні величини росту у 2015 році зафіксовані на початку червня. Для характеристики господарської якості галицького коропа проведено оцінку екстер'єрних показників протягом вететаційного сезону. Виявлено, що трилітки характеризуються високим темпом росту, мають невелику голову та м'ясисту структуру. Трилітки галицького коропа, отримані в ставових умовах Прикарпаття відзначаються високими господарськими показниками як за індивідуальною масою риб, так $i$ за загальною рибопродуктивністю. Галицький короп є високопродуктивним та перспективним об'єктом для подальшого відновлення аборигенного складу культивованих видів риб у ставовому рибництві Прикарпаття.

Ключові слова: темп росту, екстер'єр, галицький короп, питома швидкість росту, масонакопичення.

Постановка проблеми. В останні роки простежується тенденція до збільшення видового складу культивованих видів риб. Важливе значення належить і відродженню в Україні цінних аборигенних малопоширених масивів коропа, зокрема галицького коропа. Тому вивчення та аналіз продуктивних характеристик цього коропа в умовах сучасного промислового вирощування набуває особливої актуальності.
Галицький короп заслуговує уваги, адже представники цього масиву залишились лише у декількох господарствах Львівської області. Отже, для промислового відтворення та оцінки галицького коропа, як об'єкта промислового вирощування, необхідне вивчення його продуктивних можливостей на різних ланках технологічного процесу.

Аналіз основних досліджень і публікацій, у яких започатковано розв'язання проблеми. Одним зі специфічних напрямів тваринництва у складі агропромислового комплексу становить аквакультура. Ї̈̈ розвиток зумовлює не тільки ефективне використання територій сільськогосподарського призначення, а й збільшення обсягів виробництва продукції рибництва та цінних видів гідробіонтів [6, 7].

Територія Львівщини налічує близько 15,1 тис. га внутрішніх водойм, більшість 3 яких набули рибогосподарського значення. Перехід до ринкової економічної системи зумовив загальний спад виробництва продукції рибництва, що призвело до зменшення обсягів споживання населенням рибної продукції $[3,4]$

У цей час перед рибним господарством постає завдання забезпечити населення продукцією високої якості. Вирішальним критерієм для споживача є доступність та високий рівень господарської цінності риби. Згідно з останніми тенденціями ринку, основу споживчого попиту становлять коропи з малолускатим або голим покривом тіла, які повинні мати підвищенні вагові кондиціï $[8,9]$.

Одним 3 основних критеріїв для вибору високоякісної рибної продукції є середня маса певного екземпляра. Підвищити яку можна за допомогою трилітнього циклу вирощування коропа. Досягнення поліпшених показників рибопродукції здійснюється за допомогою інтенсифікаційних заходів, спрямованих на підвищення якості вирощуваних риб [5].

Одним із найважливіших шляхів інтенсифікації є поліпшення продуктивних якостей об'єктів вирощування, яке досягається шляхом створення 


\section{СІЛЬСЬКЕ ГОСПОДАРСТВО. ТВАРИННИЦТВО}

нових або відновленням аборигенних високопродуктивних порід риб. Особливої уваги потребують об'єкти вирощування, які користуються підвищеним попитом завдяки своїм гастрономічним властивостям та швидкому темпу росту. Адже ці критерії є основними під час визначення конкурентоспроможності та якості рибної продукції [11].

Мета досліджень - визначити основні рибогосподарські характеристики триліток галицького коропа, отриманих в умовах ставового вирощування.

Завдання досліджень - проаналізувати динаміку росту та швидкість масонакопичення протягом вегетаційного сезону. Провести господарську оцінку товарних триліток галицького коропа, вирощених у промислових умовах Прикарпаття.

Методика проведення досліджень. Вирощування триліток галицького коропа проходило за умов монокультури у ставах фермерського господарства «Короп». Площа дослідного ставу сягала 0,4 га. Зарибнення ставу проводили дворічками галицького коропа, середня маса яких становила 1,5 кг. Перед посадкою рибопосадкового матеріалу в ставах проводили профілактичні та меліоративні заходи. Густота посадки риб становила 1250 екз./га.

Протягом вегетаційного періоду вивчався екологічний стан утримання риб за гідрохімічними показниками ставу та розвитком кормової бази $[1,12]$.
Основні рибницько-біологічні показники триліток галицького коропа досліджували під час контрольних ловів, весняної інвентаризації та осінніх обловів за загальноприйнятими в рибництві методами. Для оцінки господарської якості галицького коропа проведено оцінку екстер'єрних показників протягом вегетаційного сезону [2, 12].

Характеристику росту триліток галицького коропа проводили на підставі приростів протягом вегетаційного сезону та питомої швидкості приросту риб за I. I. Шмальгаузеном [13].

Результати досліджень. Екологічні умови під час вирощування триліток галицького коропа були в межах рибницьких вимог. Протягом вегетаційного сезону проводили підгодівлю риб зерном пшениці, добовий раціон розраховували згідно $з$ методичними рекомендаціями [12].

Протягом вегетаційного сезону проводили контрольні лови вирощених триліток галицького коропа. Відмічено найбільш інтенсивне збільшення маси риб протягом обох років дослідження на початку липня та в першій декаді вересня. Результати контрольних ловів представлені у рисунку 1.

Найменші показники вагового росту протягом 2016 року спостерігалися у травні. В цей період приріст галицького коропа в середньому не перевищив 20 г. Найнижчим показник зростання в абсолютних величинах у 2015 році встановлено на рівні 10 г. Ця тенденція прослідковувалась на початку травня та липня.

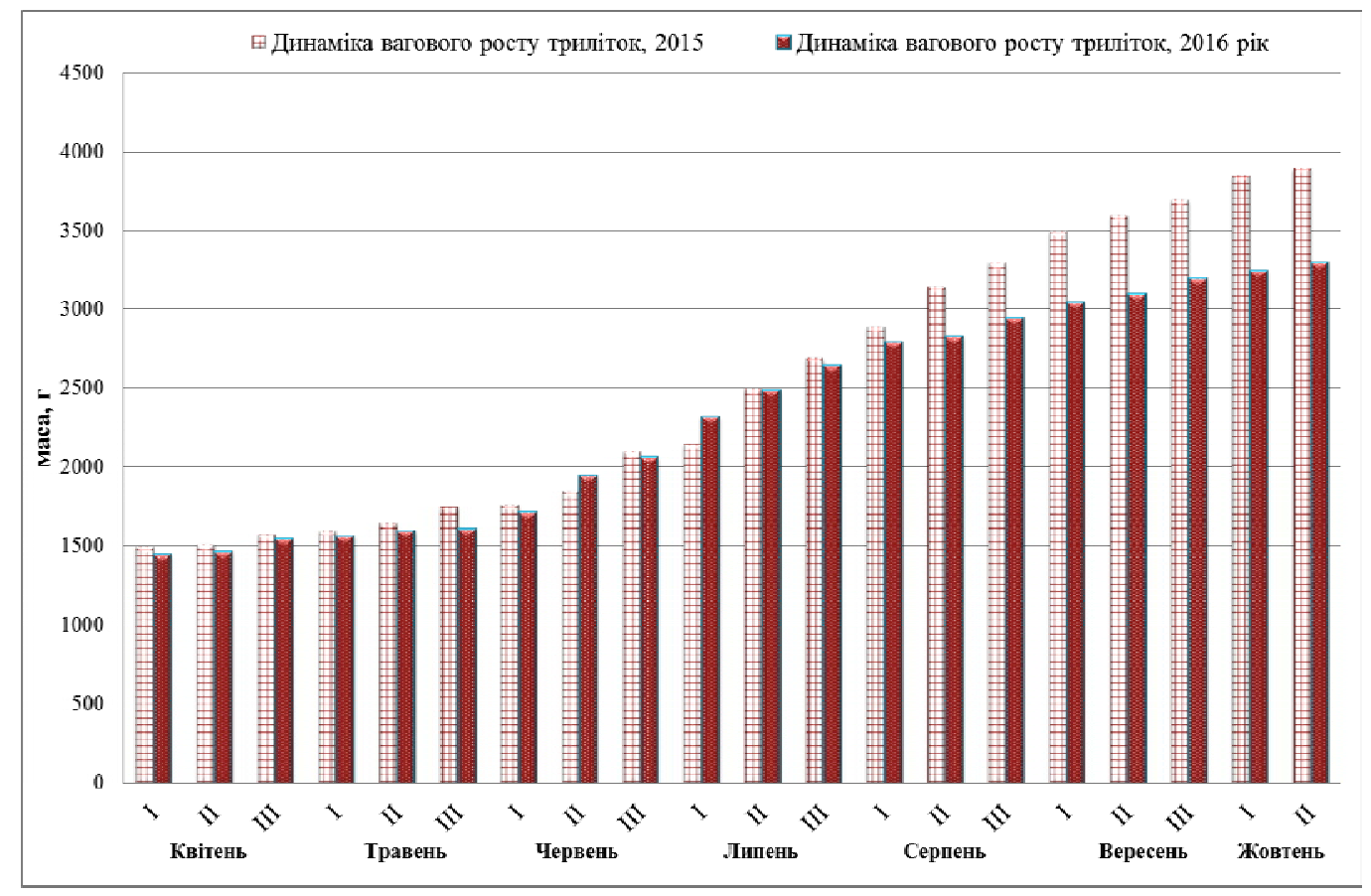

Рис. 1. Динаміка вагового росту триліток галицького коропа господарства «Короп» 


\section{СІЛЬСЬКЕ ГОСПОДАРСТВО. ТВАРИННИЦТВО}

Найбільшим показник відносного приросту у 2015 році спостерігався на рівні $14 \%$, який зафіксовано у другій декаді липня. Він перевищив 2016 рік майже вдвічі. Найнижчий показник відносного приросту у 2015 році відмічено близько $2 \%$ на початку травня та в червні.

У 2016 році зафіксовано декілька піків віднос- ного приросту. Так найбільші значення цього показника варіювали в межах від 10 до 12 \%. Ця тенденція прослідковувалась у другій декаді червня та в першій декаді липня. Найнижче значення близько 1 \% зафіксовано у третій декаді травня (рис. 2).

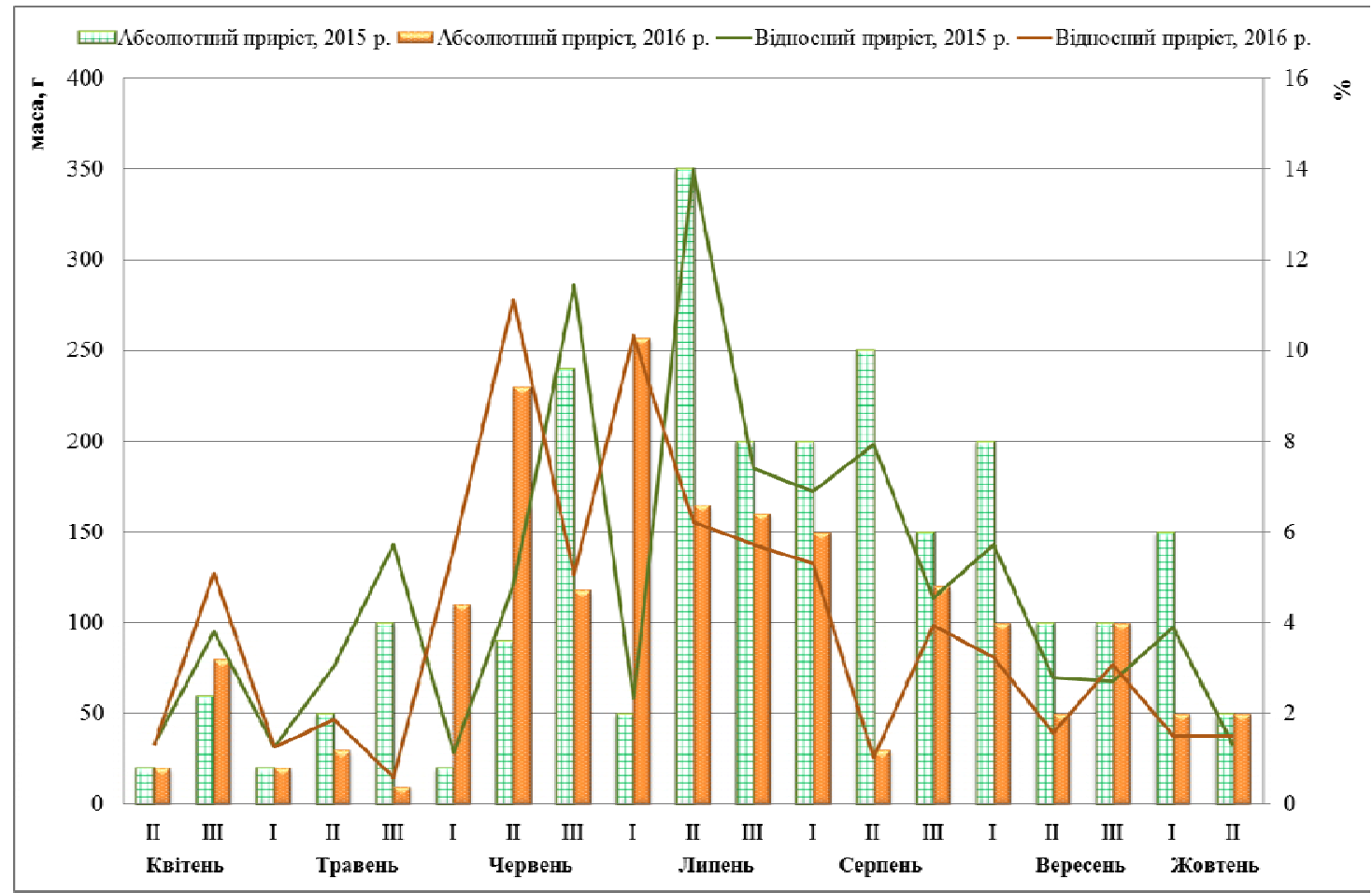

Рис. 2. Приріст триліток галицького коропа у 2015-2016 роках

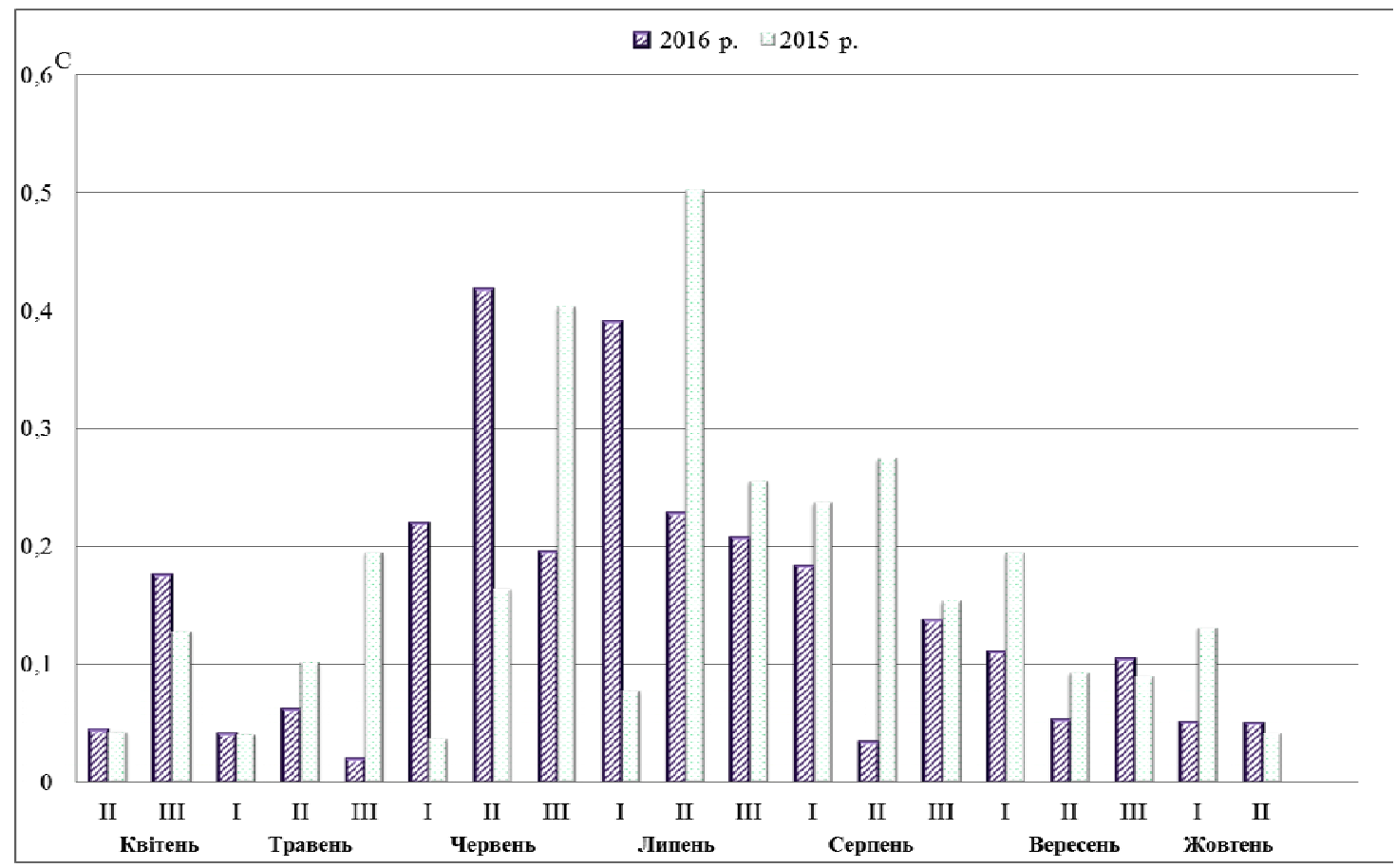

Рис. 3. Динаміка питомої ивидкості росту триліток галицького коропа господарства «Короп» 
СІЛЬСЬКЕ ГОСПОДАРСТВО. ТВАРИННИЦТВО

\section{1. Ерективність вирощування галицького коропа у господарстві «Короп»}

\begin{tabular}{|c|c|c|}
\hline \multirow{2}{*}{ Показники } & \multicolumn{2}{|c|}{ Роки } \\
\cline { 2 - 3 } & 2015 & 2016 \\
\hline Площа ставу, га & \multicolumn{2}{|c|}{0,4} \\
\hline Густота посадки, екз./га & 1250 & 1250 \\
\hline Середня маса рибопосадкового матеріалу, кг & 1500 & 1450 \\
\hline Посаджено трирічок, екз. & 500 & 500 \\
\hline Виловлено триліток, екз. & 490 & 390 \\
\hline Рибопродукція, кг/га & 4700 & 2220 \\
\hline Загальна рибопродуктивність, кг/га & 2940 & 3300 \\
\hline Середня маса триліток, г & 3900 & 96 \\
\hline Вихід триліток, \% & 98 & 3,0 \\
\hline Витрати кормів на одиницю приросту маси риб, од. & 3,0 & \\
\hline
\end{tabular}

\section{2. Екстер'єрні показники триліток галицького коропа (n=10)}

\begin{tabular}{|c|c|c|c|c|c|c|c|c|}
\hline \multirow{2}{*}{ Дата } & \multicolumn{3}{|c|}{ Maca, $\Gamma$} & \multirow{2}{*}{ Квг } & \multicolumn{4}{|c|}{ Показники екстер'єру: } \\
\hline & $\max$ & $\min$ & $\underline{\mathrm{M} \pm \mathrm{m}}$ & & $1 / \mathrm{H}$ & $1 / \mathrm{O}$ & $1 / \mathrm{C}$ & $1 \mathrm{xB} / \mathrm{hXB}$ \\
\hline 31.03 .2016 & 1700 & 1100 & $1450 \pm 181$ & 3,0 & 2,5 & 1,4 & 4,4 & 1,6 \\
\hline $\mathrm{CV}$ & - & - & 14,6 & 15,4 & 10,8 & 7,8 & 3,6 & 19,8 \\
\hline$\sigma$ & & & 209 & 0,4 & 0,3 & 0,1 & 0,2 & 0,3 \\
\hline 15.07 .2016 & 2800 & 1800 & $2325 \pm 275$ & 3,25 & 2,5 & 1,1 & 3,7 & 1,3 \\
\hline $\mathrm{CV}$ & - & - & 13,9 & 7,7 & 10,2 & 0,5 & 5,44 & 8,6 \\
\hline$\sigma$ & & & 325,1 & 0,3 & 0,3 & 4,4 & 0,2 & 0,1 \\
\hline 15.10 .2016 & 3750 & 2900 & $3287 \pm 242$ & 3,4 & 2,2 & 1,1 & 3,8 & 1,1 \\
\hline $\mathrm{CV}$ & - & - & 8,6 & 10,2 & 6,6 & 0,3 & 2,5 & 4,8 \\
\hline$\sigma$ & - & - & 285,3 & 0,4 & 0,2 & 3,3 & 0,1 & 0,1 \\
\hline
\end{tabular}

Аналіз зростання вагових кондицій триліток галицького коропа проведено за допомогою показника питомої швидкості росту. Протягом 2016 року зафіксовано декілька піків швидкості масонакопичення. Максимальне зростання в цьому році спостерігається у другій декаді червня та в першій декаді липня. Найнижчим показник масонакопичення у 2016 році зареєстровано у третій декаді травня та в другій декаді серпня.

У 2015 році показник питомої швидкості росту (С) отримав своє максимальне значення у другій декаді липня. Проте високі показники швидкості масонакопичення триліток галицького коропа зафіксовано також і в третій декаді червня та в другій декаді серпня. Найменша швидкість зростання спостерігається на початку червня. Динаміка питомої швидкості росту представлена на рисунку 3 .

Після облову дослідного ставу середня маса виловлених триліток галицького коропа протягом дослідного періоду перевищила 3 кг. Вихід становив від $96 \%$ до $98 \%$. Показники ефективності вирощування галицького коропа у фермерському господарстві «Короп» наведено у таблиці 1.
Після зимівлі коефіцієнт вгодованості рибопосадкового матеріалу знаходився на рівні 3,0 , в кінці вегетаційного сезону відбулось його збільшення на $13 \%$ (табл. 2).

Протягом вегетаційного сезону відбулось зменшення індекса голови на $16 \%$, індекса хвостового стебла - на $45 \%$. Трилітки галицького коропа характеризуються високоспинною тілобудовою, про що свідчить індекс високоспинності $(2,2-2,5)$.

Висновок. Трилітки галицького коропа, отримані в ставових умовах Прикарпаття відзначаються високими господарськими показниками як за індивідуальною масою риб, так і за загальною рибопродуктивністю. Окрім високої індивідуальної маси трилітки характеризувались відносно невеликою головою та високоспинністю за екстер'єром, що свідчить про м'ясисту тілобудову.

Отже, галицький короп є високопродуктивним та перспективним об'єктом для відновлення аборигенного складу культивованих видів риб у ставовому рибництві Прикарпаття. 


\section{БІБЛІОГРАФІЯ}

1. Алекин $O$. А. Руководство по химическому анализу вод суши / О. А. Алекин, А. Д. Семенов, Б. А. Скопинцев. - Львів : Гидрометеоиздат, 1973. $-262 \mathrm{c}$.

2. Галасун П. Т. Рыбоводно-биологический контроль в прудовых хозяйствах / П. Т. Галасун. - М. : Пищевая промышленность, 1976. - 127 с.

3. Гринжевський М. В., Пекарський А. В. Економічна ефективність вирощування товарної риби за трилітнього циклу / М. В. Гринжевський, А. В. Пекарський. - К. : Світ, 2000. - 164 с.

4. Гринжевський М. В., Пекарський А. В. Економічна ефективність вирощування товарної риби за трилітнього циклу / М. В. Гринжевський, А. В. Пекарський. - К. : Світ, 2000. - 164 с.

5. Гринжевський М. В. Ефективність інтенсифікації ставового рибництва в сучасних умовах / М.В.Гринжевський, Й. Є. Янінович, Т. М. Швець // Рибогосподарська наука України. - 2007. №2. - C. 34-40.

6. Гриииняк I. I. Історичні аспекти, стан та перспективи розвитку рибогосподарської діяльності на внутрішніх водоймах України / I. I. Грициняк, О. М. Третяк, О. М. Колос // Вісник Сумського національного аграрного університету. Серія : Тваринництво. - 2014. - №2 (1). - С. 22-30.

7. Грициняк I. I. Наукове забезпечення розвитку аквакультури та підвищення ефективності використання водних біоресурсів внутрішніх водойм України / I. І. Грициняк // Рибогосподарська наука України. - 2010. - №1. - С. 4-13.

8. Гурбик В. В., Грициняк I. I. Оцінка товарних кондицій різновікових груп галицького коропа / В. В. Гурбик, I. I. Грициняк // Науковий вісник ЛНУВМБТ імені С. З. Гжицького. - 2017. - Т. 19, №74. - C. 29-32.

9. Поддубная A. B. Карп как продукт питания. Ориентиры для селекции / А. В. Поддубная // Генетика, селекция, племенное дело и воспроизводство рыб : междунар. конф. : мат. СПб., 2008. - С. 67-68.

10. Методические рекомендации по сбору и обработке материалов при гидробиологических исследованиях на пресноводных водоемах. Зообентос и его продукция. - Львів, 1982. - 51 с.

11. Олексієнко О. О. Антонінсько-зозуленецький тип - структурна ланка українських порід коропа / О. О. Олексієнко // Таврійський науковий вісник. - 2004. - Вип. 32. - С. 157-163.

12. Сяра Я.И. Методические указания по гидрохимическим исследованиям в прудовых рыбных хозяйствах / Я. И. Сяра. - Львов : Вільна Україна, 1978. - 17 с.

13. Шмальгаузен И. И. Определение основных понятий и методика исследования роста / И. И. Шмальгаузен // Рост животных. - М., 1935. - C. 8-60. 